\title{
Studies on Effect of Methods of Sowing and Integrated Nutrient Management in Late Sown Wheat (Triticum aestivum L.)
}

\author{
Aditya Singh, D.D. Yadav, Rentapalli Balaji*, Prabhakara Reddy Kallam, \\ Manish Bhatt and Prabin Dawadee
}

Department of Agronomy, Chandra Shekhar Azad University of Agriculture and Technology, Kanpur, UP-2008002, India

*Corresponding author

\begin{tabular}{|l|}
\hline Ke y w o r d s \\
Late sown, INM, \\
Azotobacter, \\
Economics, \\
Vermicompost \\
\hline Article Info \\
\hline $\begin{array}{l}\text { Accepted: } \\
22 \text { April } 2018 \\
\text { Available Online: } \\
\text { 10 May } 2018\end{array}$ \\
\hline
\end{tabular}

\section{Introduction}

Wheat is the most important staple food grain crop in Indian diet and main source of protein and calories for a large section of population. By 2020, India will have a population of about 1.3 billion and there will be a substantial

\section{A B S T R A C T}

A field experiment was conducted during Rabi 2013-14 and 2014-15 at Chandra Shekhar Azad University of Agriculture and Technology, Kanpur with a view to assess the effect of methods of sowing and integrated nutrient management on growth, yield attributes grain yield and economics in late sown wheat cv. HUV-234. The experiment was laid out in a Split plot design with three replications. Treatment were three methods of sowing [broadcasting of the seed $-\mathrm{M}_{1}$, Line sowing (20cm apart) $-\mathrm{M}_{2}$ and cross sowing $-\mathrm{M}_{3}$ ] in main plots and seven nutrient management practices [with Control $-\mathrm{N}_{1}$, RDF $100 \%-\mathrm{N}_{2}$, $\mathrm{RDF}+\mathrm{FYM} @ 5.0 \mathrm{t} \mathrm{ha} \mathrm{h}^{-1}-\mathrm{N}_{3}, \mathrm{RDF}+\mathrm{FYM} @ 2.5 \mathrm{t} \mathrm{ha}^{-1}+\mathrm{PSB}+$ Azotobactor + Trichoderma - $\mathrm{N}_{4}, \mathrm{RDF}+$ Vermicompost @ $2.0 \mathrm{t} \mathrm{ha}^{-1}-\mathrm{N}_{5}, \mathrm{RDF}+$ Vermicompost @ $1.0 \mathrm{t}$ $\mathrm{ha}^{-1}+$ PSB + Azotobactor + Trichoderma $-\mathrm{N}_{6}$ and RDF + FYM @ $2.5 \mathrm{t} \mathrm{ha}^{-1}+$ Vermicompost @ $1.0 \mathrm{t} \mathrm{ha}^{-1}+$ PSB + Azotobacter + Trichoderma $\left.-\mathrm{N}_{7}\right]$ in sub plots. Results revealed that among the methods of sowing, cross sowing perform regarding yield and yield attributes with significantly highest grain and straw yield $(38.85,61.84 \mathrm{q} / \mathrm{ha}$ ) than M1 (35.93, $57.55 \mathrm{q} / \mathrm{ha})$ and M2 $(36.78,57.94 \mathrm{q} / \mathrm{ha})$ and net profit (Rs. $108902 / \mathrm{ha})$ over M1 (Rs. $96994 /$ ha), M2 (Rs. $99732 /$ ha) respectively. B: C ratio was also recorded highest (3.53) in cross sowing. Among the nutrient management practices T7 perform regarding yield and yield attributes with significantly highest grain (50.98 q/ha), straw yield (76.31 q/ha) and net profit (Rs. 147942 /ha) and B: C ratio (4.44) over rest of the treatments. It was also noted that integrated nutrient management practices perform significantly better than RDF alone and control. Treatment combination M3 x N7 recorded significantly better yield attributes with highest grain and straw yield (52.87 q/ha, $78.84 \mathrm{q} / \mathrm{ha}$ ), net profit (Rs. 154517 /ha) and B: C ratio (4.59) than rest of the combinations respectively. 
increase the wheat productivity. The use of organic manures improves soil physical, chemical and biological properties and fertilizer use efficiency, mitigates short supply of micro nutrients and plays an important role in the maintenance of soil fertility and improves the ecological balance of rhizosphere. Use of a chemical fertilizer or organic manure alone cannot achieve and sustain the desired level of crop production under intensive cropping. Conjoint use of organic manures and chemical fertilizers is very essential as thus not only sustains higher level of productivity but also improves soil health and enhances the nutrients use efficiency. Under specific circumstances wheat is sown in the month of December too. In late sown wheat, only short duration varieties should be sown because there is comparatively less reduction in their yields compared to long duration varieties. Late sowing usually results in a poor stands as well as the inadequate vegetative growth of crop. The reproductive development in late sown wheat is also poor on account of the quick rise of ambient temperature towards the maturity stage. Methods of sowing wheat is also play an important to maintain the plant population as well as plant geometry to provide for individual plant, though plant have plasticity but up to some extent. Thus plant geometry provided sub optimum condition for growth and development of plant keeping above facts in view the experiment was carried out to obtain the maximum productivity under late sown conditions.

\section{Materials and Methods}

The experiment was carried out during Rabi seasons of 2013-14 and 2014-15 at SIF farm of C.S. Azad University of Agriculture and Technology, Kanpur. The soil of experimental plot was sandy loam and nearly neutral in reaction $(\mathrm{pH}$ 7.7) and low in organic carbon $(0.47 \%)$, available nitrogen (223 $\left.\mathrm{kg} \mathrm{ha}^{-1}\right)$, available phosphorus (12.6 $\left.\mathrm{kg} \mathrm{ha}^{-1}\right)$ and potassium $\left(177 \mathrm{~kg} \mathrm{ha}^{-1}\right)$. The experiment was laid out in split plot design with treatments were consisted under the three methods of sowing and seven nutrient management practices. Under methods of sowing broadcasting of the seed $\left(\mathrm{M}_{1}\right)$, Line sowing (20 cm apart) $\left(\mathrm{M}_{2}\right)$ and cross sowing $\left(\mathrm{M}_{3}\right)$ were practiced. Under nutrient management practices Control $\left(\mathrm{N}_{1}\right)$, RDF $100 \%\left(\mathrm{~N}_{2}\right)$, RDF +FYM@5.0 tha ${ }^{-1}\left(\mathrm{~N}_{3}\right), \mathrm{RDF}+\mathrm{FYM} @ 2.5 \mathrm{t}$ $\mathrm{ha}^{-1}+\mathrm{PSB}+$ Azotobactor + Trichoderma $\left(\mathrm{N}_{4}\right), \mathrm{RDF}+$ Vermicompost @ $2.0 \mathrm{tha}^{-1}\left(\mathrm{~N}_{5}\right)$, RDF+Vermicompost@1.0 tha ${ }^{-1}+$ PSB + Azotobactor + Trichoderma $\left(\mathrm{N}_{6}\right)$ and $\mathrm{RDF}+$ FYM @ $2.5 \mathrm{t} \mathrm{ha}^{-1}+$ Vermicompost @ $1.0 \mathrm{t}$ $\mathrm{ha}^{-1}+\mathrm{PSB}+$ Azotobacter + Trichoderma $\left(\mathrm{N}_{7}\right)$ were tested. The crop variety HUW-234 was sown @ $125 \mathrm{~kg} \mathrm{ha}^{-1}$ on $10^{\text {th }}$ December and $12^{\text {th }}$ December during 2013 and 2014, respectively. The other management practices as per standard recommendation of the region. Harvesting was done on $18^{\text {th }}$ April in 2014 and $21^{\text {st }}$ April in 2015.

\section{Results and Discussion}

\section{Effect of different treatments on late sown wheat}

\section{Growth characteristics}

The plant height $(108.08 \mathrm{~cm})$ was observed highest under the treatment $\mathrm{T}_{7}$ i.e. the combination of RDF + FYM @ $2.5 \mathrm{t} \mathrm{ha}^{-1}+$ Vermicompost @ $1.0 \mathrm{t} \mathrm{ha}^{-1}+$ PSB + Azotobacter + Trichoderma and lowest under control treatment $(49.11 \mathrm{~cm}$ ) (Kachroo and Razdon, 2006).

No. of ear $\mathrm{m}^{-2}$ at maturity stage found significantly higher in $\mathrm{M}_{3}$ (360.43) than $\mathrm{M}_{1}$ (312.70) as well as under nutrient management practice in treatment $\mathrm{T}_{7}$ recorded higher number of ear $\mathrm{m}^{-2}$ (441.92) and lowest in control (225.60). Ear head was significantly 
response with cross sowing method and combined application of RDF + FYM @ $2.5 \mathrm{t}$ $\mathrm{ha}^{-1}+$ Vermicompost @ $1.0 \mathrm{t} \mathrm{ha}^{-1}+\mathrm{PSB}+$ Azotobacter + Trichoderma $\left(\mathrm{T}_{7}\right)$. It was probably due to positive effect of methods of sowing and bio fertilizer/FYM combined with nitrogenous fertilizer. (Chaudhary et al., 2005).

Number of tillers $\mathrm{m}^{-2}$ in different treatments were found significantly higher in cross sowing method (372.62) and lowest in broadcasting method (323.06) as well as showed significant response with application of RDF + FYM@ $2.5 \mathrm{t} \mathrm{ha}^{-1}+$ Vermicompost @ $1.0 \mathrm{t} \mathrm{ha}^{-1}+\mathrm{PSB}+$ Azotobacter + Trichoderma(T7) (453.87). This treatment is at par with the treatments $\mathrm{T}_{6}, \mathrm{~T}_{5}$ and $\mathrm{T}_{4}$. The minimum number of tillers $\mathrm{m}^{-2}$ (234.66) was observed under control plot. It indicates the total tillers were found significantly higher under cross sowing method and combined application of RDF + FYM @ $2.5 \mathrm{t} \mathrm{ha}^{-1}+$ Vermicompost @ $1.0 \mathrm{t} \mathrm{ha} \mathrm{ha}^{-1}+\mathrm{PSB}+$ Azotobacter + Trichoderma.

Fresh dry weight (28.16 and $30.74 \mathrm{~g}$ ) recorded at maturity under cross sowing method $\mathrm{T}_{7}$ was maximum with combined application of RDF +FYM@2.5 t ha ${ }^{-1}+$ Vermicompost@1.0 t ha $^{-1}$ + PSB + Azotobacter + Trichoderma as well as lowest under $\mathrm{M}_{1}$ (130.88) and control (121.60).

It was also showed statistically at par with $\mathrm{T}_{4}$ and $\mathrm{T}_{6}$. It was probably due to positive effect of cross sowing method and bio fertilizer/FYM combined with nitrogenous fertilizer (Abbas et al., 2009).

Dry weight was obtained higher under method of sowing in cross sowing method (28.16g) but lowest under $\mathrm{M}_{1}(26.60 \mathrm{~g})$ as well as $30.74 \mathrm{~g}$ dry weight recorded at complete maturity stage were significantly higher with combined application of RDF + FYM @ $2.5 \mathrm{t}$ $\mathrm{ha}^{-1}+$ Vermicompost @ $1.0 \mathrm{t} \mathrm{ha}^{-1}+$ PSB + Azotobacter + Trichoderma by treatment $\mathrm{T}_{7}$. Cross sowing and combined application of RDF + FYM @ $2.5 \mathrm{t} \mathrm{ha}^{-1}+$ Vermicompost@ $1.0 \mathrm{t} \mathrm{ha}^{-1}$ + PSB + Azotobacter + Trichoderma manifested akin response to solitary broadcasting and application of RDF + Vermicompost @ $1.0 \mathrm{t} \mathrm{ha}^{-1}+\mathrm{PSB}+$ Azotobactor + Trichoderma. It was probably due to positive effect of method of sowing and bio fertilizer/ FYM with nitrogen (Mashoor et al., 2001).

\section{Yield attributing characters}

The maximum length of spike $10.77 \mathrm{~cm}$ was recorded under $\mathrm{M}_{3}$ and lowest under $\mathrm{M}_{1}$ $(10.19 \mathrm{~cm})$.

The length of the spike was significantly higher at maturity stage with combined application of RDF + FYM @ $2.5 \mathrm{t} \mathrm{ha}^{-1}+$ Vermicompost @ $1.0 \mathrm{t} \mathrm{ha}^{-1}+\mathrm{PSB}+$ Azotobacter + Trichoderma (11.76) followed by RDF + Vermicompost @ $1.0 \mathrm{t} \mathrm{ha}^{-1}+$ PSB + Azotobactor + Trichoderma (11.28) as compared to control (9.50). It might be due to method of sowing and integration of organic and inorganic sources (Ardakani et al., 2001).

The number of spikelets/spike 18.88 were recorded significantly maximum with cross sowing method broadcasting (17.86) as well as under nutrient management practices obtained 20.60 which was higher in combined application of RDF + FYM @ $2.5 \mathrm{t} \mathrm{ha}^{-1}+$ Vermicompost @ $1.0 \mathrm{t} \mathrm{ha}^{-1}+\mathrm{PSB}+$ Azotobacter + Trichoderma while lowest in control (16.64). The treatment i.e. $\mathrm{T}_{7} \mathrm{RDF}+$ FYM@2.5 t ha ${ }^{-1}+$ Vermicompost@1.0 t $\mathrm{ha}^{-1}+$ PSB + Azotobacter + Trichoderma was showed statistical at par with $\mathrm{T} 6$ and $\mathrm{T}_{4}$. Combined application of bio fertilizer and vermicompost gave significantly superior response over control (Brick and Goswami, 2003). 
Table.1 Effect of sowing methods and nutrient management on growth of wheat

\begin{tabular}{|c|c|c|c|c|c|}
\hline \multicolumn{3}{|c|}{ Treatment } & \multicolumn{3}{|c|}{ Character } \\
\hline $\begin{array}{l}\text { Methods of } \\
\text { sowing }\end{array}$ & $\begin{array}{l}\text { Plant height } \\
(\mathrm{cm}) \text { at maturity } \\
\text { stage }\end{array}$ & $\begin{array}{l}\text { Number of } \\
\text { Tillers } \mathrm{m}^{-2}\end{array}$ & $\begin{array}{l}\text { Number of ear } \\
\text { heads } \mathrm{m}^{-2}\end{array}$ & $\begin{array}{l}\text { Fresh weight }(\mathrm{g}) \\
\text { at maturity stage }\end{array}$ & $\begin{array}{l}\text { Dry weight(g) at } \\
\text { maturity stage }\end{array}$ \\
\hline $\mathbf{M}_{1}$ & 93.69 & 323.06 & 312.70 & 26.60 & 20.54 \\
\hline $\mathbf{M}_{2}$ & 96.74 & 352.44 & 340.07 & 27.52 & 21.21 \\
\hline $\mathbf{M}_{3}$ & 99.01 & 372.62 & 360.49 & 28.16 & 21.71 \\
\hline SED & 1.05 & 4.14 & 2.98 & 0.33 & 0.25 \\
\hline $\mathrm{CD}(\mathrm{p}=0.05)$ & 2.90 & 11.89 & 8.24 & 0.93 & 0.71 \\
\hline \multicolumn{6}{|c|}{ Nutrient management } \\
\hline $\mathrm{T}_{1}$ & 87.31 & 234.66 & 225.26 & 24.83 & 19.14 \\
\hline$T_{2}$ & 89.76 & 301.05 & 289.79 & 25.53 & 19.68 \\
\hline $\mathbf{T}_{3}$ & 92.52 & 322.87 & 313.21 & 26.20 & 20.29 \\
\hline$T_{4}$ & 98.93 & 358.05 & 366.19 & 28.14 & 21.70 \\
\hline$T_{5}$ & 95.05 & 378.55 & 344.85 & 27.04 & 20.84 \\
\hline$T_{6}$ & 103.72 & 396.58 & 383.05 & 29.50 & 22.74 \\
\hline $\mathrm{T}_{7}$ & 108.08 & 453.87 & 441.92 & 30.74 & 23.70 \\
\hline SED & 3.01 & 6.24 & 4.23 & 0.47 & 0.40 \\
\hline $\mathrm{CD}(\mathrm{p}=0.05)$ & 1.48 & 12.72 & 8.58 & 0.97 & 0.81 \\
\hline SED $(M \times$ x T) & 2.57 & 10.82 & 7.33 & 0.83 & 0.69 \\
\hline $\mathrm{CD}(\mathrm{M} \times \mathrm{T})$ & NS & NS & NS & NS & NS \\
\hline
\end{tabular}

Table.2 Effect of sowing methods and nutrient management on yield attributing characters of wheat

\begin{tabular}{|c|c|c|c|c|c|c|c|}
\hline \multirow{2}{*}{$\begin{array}{l}\text { Treatment } \\
\text { Methods of } \\
\text { sowing }\end{array}$} & \multicolumn{7}{|c|}{ Character } \\
\hline & $\begin{array}{l}\text { Number of } \\
\text { spikelets per } \\
\text { ear }\end{array}$ & $\begin{array}{l}\text { Length of } \\
\text { spikelet } \\
(\mathrm{cm})\end{array}$ & $\begin{array}{l}\text { Weight of } \\
\text { spikelet } \\
\text { (g) }\end{array}$ & $\begin{array}{l}\text { Number of } \\
\text { grains per } \\
\text { ear }\end{array}$ & $\begin{array}{l}\text { Weight of } \\
\text { grains per } \\
\text { ear }\end{array}$ & $\begin{array}{l}1000 \\
\text { grains } \\
\text { weight (g) }\end{array}$ & $\begin{array}{l}\text { Protein } \\
\text { yield ( } \mathrm{q} \\
\left.\mathrm{ha}^{-1}\right)\end{array}$ \\
\hline $\mathbf{M}_{1}$ & 17.86 & 10.19 & 3.25 & 41.49 & 2.60 & 41.95 & 4.14 \\
\hline $\mathbf{M}_{2}$ & 18.44 & 10.52 & 3.35 & 42.85 & 2.79 & 42.10 & 4.28 \\
\hline $\mathbf{M}_{3}$ & 18.88 & 10.77 & 3.43 & 43.85 & 2.74 & 42.13 & 4.57 \\
\hline SED & 0.16 & 0.06 & 0.06 & 0.41 & 0.04 & 0.04 & 0.15 \\
\hline$C D(p=0.05)$ & 0.44 & 0.19 & 0.15 & 1.15 & NS & NS & NS \\
\hline \multicolumn{8}{|c|}{ Nutrient management } \\
\hline $\mathrm{T}_{1}$ & 16.64 & 9.50 & 3.03 & 38.67 & 2.42 & 39.55 & 1.59 \\
\hline$T_{2}$ & 17.11 & 9.76 & 3.11 & 39.75 & 2.49 & 40.57 & 3.87 \\
\hline$T_{3}$ & 17.64 & 10.06 & 3.20 & 40.97 & 2.56 & 41.57 & 4.11 \\
\hline$T_{4}$ & 18.86 & 10.76 & 3.43 & 43.82 & 5.63 & 41.97 & 4.86 \\
\hline$T_{5}$ & 18.12 & 10.34 & 3.30 & 42.10 & 2.74 & 42.97 & 4.66 \\
\hline$T_{6}$ & 19.77 & 11.28 & 3.60 & 45.92 & 2.87 & 43.53 & 5.20 \\
\hline $\mathbf{T}_{7}$ & 20.60 & 11.76 & 3.75 & 47.86 & 2.99 & 44.34 & 6.08 \\
\hline SED & 0.23 & 0.09 & 0.09 & 0.62 & 0.06 & 0.06 & 0.19 \\
\hline$C D(p=0.05)$ & 0.48 & 0.19 & 0.20 & 1.27 & 0.14 & 0.14 & 0.39 \\
\hline SED (M x T) & 0.41 & 0.16 & 0.17 & 1.09 & 0.12 & 0.12 & 0.33 \\
\hline $\mathrm{CD}(\mathrm{M} \times \mathrm{T})$ & NS & NS & NS & NS & NS & NS & $\mathrm{NS}$ \\
\hline
\end{tabular}


Table.3 Effect of sowing methods and nutrient management on yield and economics of wheat

\begin{tabular}{|c|c|c|c|c|c|c|c|}
\hline Treatment & \multicolumn{7}{|c|}{ Character } \\
\hline $\begin{array}{l}\text { Methods of } \\
\text { sowing }\end{array}$ & $\begin{array}{l}\text { Grain } \\
\text { yield (q } \\
\left.\text { ha }^{-1}\right)\end{array}$ & $\begin{array}{l}\text { Straw } \\
\text { yield (q } \\
\left.\text { ha }^{-1}\right)\end{array}$ & $\begin{array}{l}\text { Biomass } \\
\text { yield (q } \\
\left.\text { ha }^{-1}\right)\end{array}$ & $\begin{array}{l}\text { Harvest } \\
\text { index }\end{array}$ & $\begin{array}{l}\text { Gross } \\
\text { return (Rs } \\
\left.\mathrm{ha}^{-1}\right)\end{array}$ & $\begin{array}{l}\text { Net return } \\
\left(\mathrm{Rs} \mathrm{ha}^{-1}\right)\end{array}$ & $\mathrm{B}: \mathrm{C}$ ratio \\
\hline $\mathbf{M}_{1}$ & 35.93 & 57.55 & 93.37 & 38.25 & 139997.00 & 96994.00 & $1: 3.26$ \\
\hline $\mathbf{M}_{2}$ & 36.78 & 57.94 & 94.56 & 38.43 & 142734.00 & 99731.00 & $1: 3.32$ \\
\hline $\mathbf{M}_{3}$ & 38.85 & 61.84 & 100.95 & 38.58 & 151905.00 & 108902.00 & $1: 3.53$ \\
\hline SED & 0.60 & 1.10 & 1.34 & 0.20 & & & \\
\hline$C D(p=0.05)$ & 1.66 & 3.03 & 3.72 & 0.50 & & & \\
\hline \multicolumn{8}{|c|}{ Nutrient management } \\
\hline $\mathrm{T}_{1}$ & 14.46 & 24.31 & 38.83 & 37.24 & 59745.00 & 16742.00 & $1: 1.39$ \\
\hline $\mathbf{T}_{2}$ & 33.32 & 54.03 & 87.69 & 37.59 & 131025.00 & 88022.00 & $1: 3.05$ \\
\hline $\mathbf{T}_{3}$ & 35.87 & 58.03 & 93.56 & 37.80 & 140350.00 & 97347.00 & $1: 3.26$ \\
\hline $\mathbf{T}_{4}$ & 41.57 & 67.11 & 109.28 & 38.68 & 164030.00 & 121027.00 & $1: 3.81$ \\
\hline$T_{5}$ & 39.42 & 62.77 & 102.18 & 38.14 & 154725.00 & 111722.00 & $1: 3.60$ \\
\hline$T_{6}$ & 44.39 & 71.16 & 115.22 & 39.43 & 17330.00 & 130327.00 & $1: 4.03$ \\
\hline $\mathbf{T}_{7}$ & 50.98 & 76.31 & 127.30 & 40.03 & 190945.00 & 147942.00 & $1: 4.44$ \\
\hline SED & 0.87 & 1.69 & 2.00 & 0.30 & & & \\
\hline$C D(p=0.05)$ & 1.77 & 3.44 & 4.19 & 0.61 & & & \\
\hline $\operatorname{SED}(\mathbf{M} x \mathrm{~T})$ & 1.51 & 2.94 & 3.58 & 0.52 & & & \\
\hline $\mathrm{CD}(\mathrm{M} \times \mathrm{x})$ & 3.06 & NS & NS & NS & & & \\
\hline
\end{tabular}

Weight of spike were significantly higher at maturity stage with cross sowing method $(3.43 \mathrm{~g})$ as compared to broadcasting i.e. 3.25 as well as under nutrient management practice under combined application of RDF + FYM @ $2.5 \mathrm{t} \mathrm{ha}^{-1}+$ Vermicompost @ $1.0 \mathrm{t} \mathrm{ha}^{-1}+$ $\mathrm{PSB}+$ Azotobacter + Trichoderma obtained higher $3.75 \mathrm{~g}$ followed by RDF + Vermicompost @ $1.0 \mathrm{t} \mathrm{ha}^{-1}+$ PSB + Azotobactor + Trichoderma (3.60g) while lowest value obtained in control (3.03). The treatment cross sowing method produced significantly superior response over broadcasting but at par among themselves. It might be due to method of sowing and integration of organic and inorganic sources (Singh et al., 2004).

The number of grains per spike increased significantly higher under cross sowing method (43.85) while lowest in broadcasting
(41.49). The treatment RDF + FYM @ $2.5 \mathrm{t}$ $\mathrm{ha}^{-1}+$ Vermicompost @ $1.0 \mathrm{t} \mathrm{ha}^{-1}+$ PSB + Azotobacter + Trichoderma (47.86) as well as $\mathrm{RDF}+$ Vermicompost @ $1.0 \mathrm{t} \mathrm{ha}^{-1}+\mathrm{PSB}+$ Azotobactor + Trichoderma (45.92) found significant over control (38.67) (Kachroo and Razdon, 2006).

The weight of grain per ear $(2.74 \mathrm{~g})$ recorded at maturity stage were significantly higher with M3 while lowest under M1 (2.60g). the weight of grain per ear was obtained higher $2.99 \mathrm{~g}$ in combined application of RDF + FYM@2.5 t ha ${ }^{-1}+$ Vermicompost@1.0 t $\mathrm{ha}^{-1}+\mathrm{PSB}+$ Azotobacter + Trichoderma 9T7) as compared to control (2.42g) (Kachroo and Razdon, 2006).

The test weight was recorded significantly maximum with cross sowing method (42.13g) than broadcasting $(41.95 \mathrm{~g})$. the application of 
RDF + FYM @ $2.5 \mathrm{tha}^{-1}+$ Vermicompost @ $1.0 \mathrm{t} \mathrm{ha}^{-1}+$ PSB + Azotobacter + Trichoderma (44.34g) which was statistically at par with T4 and T6. It was also obtained lower test weight under control (39.55g) (Yadav et al., 2000) (Table 1).

\section{Yield}

Grain yield, straw yield and biological yield were recorded significantly higher with cross sowing method (38.85, 61.84 and $100.95 \mathrm{q}$ per ha) as compared broadcasting (35.93, 57.55, $93.37 \mathrm{q} \mathrm{ha}^{-1}$ ) as well as obtained higher yield 50.95, 76.31 and $115.22 \mathrm{q} \mathrm{ha}^{-1}$ with combined application of RDF + FYM @ $2.5 \mathrm{t}$ $\mathrm{ha}^{-1}+$ Vermicompost @ $1.0 \mathrm{t} \mathrm{ha}^{-1}+\mathrm{PSB}+$ Azotobacter + Trichoderma while lowest under control $\left(14.96,34.31\right.$ and $38.83 \mathrm{q} \mathrm{ha}^{1}$. Although the application of organic treatment produced significantly higher response over control but all are at par to each other (Hossain et al., 2006) (Table 2).

\section{Economics}

The gross and net return as well as benefit cost ratio were also maximized under cross sowing method. Higher gross and net return were obtained with the application of RDF + FYM@ $2.5 \mathrm{t} \mathrm{ha}^{-1}+$ Vermicompost @ $1.0 \mathrm{t}$ $\mathrm{ha}^{-1}+$ PSB + Azotobacter + Trichoderma. On average (Rs. 190945.00) in gross income and Rs. 151905.00 in net returns as well as cross sowing method (Rs.147942.00 and Rs. 104902.00) higher than the control (Rs. 16742.00 and 96994.00), respectively (Table $3)$. In other word the combined application of RDF+FYM@ 2.5 tha $^{-1}+$ Vermicompost @ $1.0 \mathrm{t} \mathrm{ha}^{-1}+$ PSB + Azotobacter + Trichoderma gave significantly higher gross and net return than sole application of organic and inorganic alone. The highest B: C ratio (4.44) was obtained with the treatments $\mathrm{T} 7$ i.e. RDF + FYM@ $2.5 \mathrm{t} \mathrm{ha}^{-1}+$ Vermicompost @ $1.0 \mathrm{t}$ $\mathrm{ha}^{-1}+$ PSB + Azotobacter + Trichoderma and lowest under control (1.39). The combined effect of inorganic fertilizer along with vermicompost and bio fertilizer have improved the yield (Pandey et al., 2009).

\section{References}

Abbas, G., M.A., Ali, G. Abbas, Azam, M. and Hussain, I., 2009. Impact of planting methods on wheat grain yield and yield contributing parameters. The Journal of Animal and Plant Sciences 19 (1): 30-33.

Ardakani, M. R., Mazaheri, D. and Noor Mohammadi, G., 2001. Effect of Azospirillum mycorrhiza and Streptomyces with manure utilization on yield and yield components of wheat. Journal of Agriculture Science Islamic Azad University. 7(1): 15-20.

Brick, A. K. and Goswami, A., 2003. Efficacy of bio fertilizer with nitrogen level on growth, productivity and economics in wheat. Indian Journal of Agronomy. 48(1): 100-102.

Chaudhary, J.B., Thakur, R.C., Bhargava, M. and Sood, R.D., 2001. Effect of level of nitrogen with FYM mulching on the yield of late sow wheat (T. aestivum) under rainfed condition. Himachal Journal of Agricultural Research, 27(1/2): 19-24.

Kachroo, D. and Rozdon, R., 2006. Growth, nutrient uptake and yield of wheat $(T$. aestivum) as influenced by bio fertilizers and nitrogen. Indian Journal of Agronomy. 15(1): 37-39.

Mashoor, W. A., Mervate, A.T.A., Sohair, A.N. and Karima, K.M., 2001. Effect of antibiotics and fungicides on persistence and survival of Azotobacter exhibiting and survival of different level of polybeta hydroxy butyrate (PUB) production and their impact on rhizospheric microorganism and wheat 
growth in sandy soil. Annals of agriculture science, 46(1): 1-21.

Md Ilias Hossain, Md Khairul Islam, and Md Abu Sufian, 2006. Effect of planting method and nitrogen levels on the yield and yield attributes of wheat. Journal of Bio-science 14: 127-130.

Pandey, I.B., Dwivedi, D.K., Pandey, P.K., 2009. Integrated nutrient management for sustaining wheat ( $T$. aestivum) production under late sown condition. Indian Journal of Agronomy. 54(3): 306-309.

Prasad R., 2012. Fertilizer and Manures. Current Science 102 (6): 894-8.
Singh, R., Bhel, R.K., Singh, K.P., Jain, P. and Narula N., 2004. Performance and gene effect of wheat yield under inoculation of orbicular mycorrhiza fungi and Azotobacter. Plant and Soil Environment, 50(9): 409-415.

Yadav, K. S., Singh, D. P., Sunya, S., Narula, N. and Lakshminarayan, K., 2000. Effect of Azotobacter on yield and nitrogen economy in wheat ( $T$. aestivum) under field condition. Environment and Ecology, 18(1): 109113.

\section{How to cite this article:}

Aditya Singh, D.D. Yadav, Rentapalli Balaji, Prabhakara Reddy Kallam, Manish Bhatt and Prabin Dawadee. 2018. Studies on Effect of Methods of Sowing and Integrated Nutrient Management in Late Sown Wheat (Triticum aestivum L.). Int.J.Curr.Microbiol.App.Sci. 7(05): 3199-3205. doi: https://doi.org/10.20546/ijcmas.2018.705.374 